\title{
A survey-based estimation of the Swiss franc forward term premium
}

\author{
Lucas Marc Fuhrer*, Basil Guggenheim and Matthias Jüttner
}

\begin{abstract}
This paper sheds light on Swiss franc LIBOR futures, which are often used to derive interest rate expectations. We show that the differences between LIBOR futures and realized rates (excess returns) are, on average, positive over the last 25 years. Using interest rate surveys, we decompose excess returns into a (forward) term premium and forecast errors. The decomposition reveals that the bulk of excess returns arises from forecast errors, while the term premium is, on average, zero but time varying. We find that the term premium positively correlates with the business cycle, interest rate developments, and in absolute values increases with interest rate uncertainty.
\end{abstract}

Keywords: Term premium, LIBOR futures, Swiss franc

JEL Classification: E43, E44, E52

\section{Introduction}

Predicting the future path of monetary policy is of great importance for financial market participants. To do so, interest rate futures are widely used by researchers, analysts, and central bankers to infer expectations of future interest rates (see, for instance, Bernanke and Kutner (2005), European Central Bank (2005), and Jordan (2012)). ${ }^{1}$

Literature has shown that differences between interest rate futures and realized rates at maturity of the futures contract, so-called excess returns, are, on average, positive and statistically and economically significant (see, e.g., Piazzesi and Swanson (2008)). Thus, interest rate futures are, on average, higher than effective realizations. Moreover, excess returns can be decomposed into a (forward) term premium and forecast errors (see, e.g., Friedman (1979)). ${ }^{2}$ While forecast errors result from false expectations (i.e., unexpected interest rate changes), the term premium is the markup that market participants are willing to pay to hedge against interest rate risks or to speculate on interest rate movements. Hence, interest rate futures may deviate from interest rate expectations due to the term premium. Findings for major currencies suggest that the predominant part of excess returns result from forecast errors, while the term premium is considerably smaller and also time varying.

*Correspondence: lucas.fuhrer@snb.ch

Schweizerische Nationalbank, Zurich, Switzerland
In this paper, we estimate excess returns in Swiss franc (CHF) interest rate futures and decompose excess returns into its two components, an analysis that has not been undertaken yet. Moreover, we contribute to the literature by shedding light on the key determinants of the term premium. The analysis is of particular interest as interest rate futures are based on the 3-month CHF London Interbank Offered Rate (LIBOR), which serves as the monetary policy target rate for the Swiss National Bank (SNB). Therefore, CHF LIBOR futures are often used as an indicator of market participants' expectations of SNB's future monetary policy and its "correct" interpretation is relevant for market participants and policy makers. To empirically identify the term premium we use a model-free approach which employs survey data on interest rates expectations (interest rate survey). Surveys cannot be traded and hence should not be influenced by any term premium. Consequently, the term premium can simply be identified as the difference between interest rate futures and interest rate expectations derived from surveys. This also implies that the term premium is known at any time, whereas forecast errors do only materialize ex-post using effective interest rate realizations.

The key findings from our analysis are as follows. First, we show that excess returns in CHF LIBOR futures are, over the last 25 years, on average positive and statistically significant which is in line with the existing literature. Being more concrete, our analysis highlights that LIBOR 
futures with a maturity date in 3 (12) months contain an average excess return of 12 (63) basis points (bps). Therefore, interest rates implied by CHF LIBOR futures are in the long run significantly higher than realized rates. Second, we find that for CHF LIBOR futures the term premium is, on average, close to zero but time varying, while forecast errors are positive on average. Positive forecast errors result in our sample period as market participants have been surprised by unexpected economic downturns and corresponding interest rate declines. Third, we show that the term premium in CHF LIBOR futures has been persistently negative between 2010 and 2016. Thus, there is evidence that in a period with close to zero or negative interest rates, market participants pay a premium to insure themselves against interest rate cuts. Fourth, we provide empirical evidence that the magnitude of the absolute term premium is affected by interest rate uncertainty. In periods where interest rate uncertainty is high, the absolute term premium (i.e., irrespective whether the term premium is positive or negative) is large. Fifth, we show that the term premium is positively related with the Swiss business cycle. In an economic upturn (downturn) the term premium is positive (negative). Related to this point, we show that the time variation in the term premium is correlated with changes in short-term interest rates. In times of increasing (decreasing) interest rates, the term premium increases (decreases). This may imply that market participants pro-cyclically hedge interest rate risks or speculate on interest rate movements.

Our results are relevant in the following ways. First, the fact that the term premium is, on average, close to zero implies that CHF LIBOR futures do not under- or overestimate interest rate expectations, on average. Second, the time variation of the term premium implies that CHF LIBOR futures can significantly deviate from interest rate expectations during certain time periods. Our results show that these deviations increase with interest rate uncertainty and are pro-cyclically related to economic variables. Thus, one conclusion could be that if CHF LIBOR futures are analyzed on a daily basis, they should be adjusted by the estimated term premium to extract interest rate expectations, especially during periods with elevated uncertainty about the future interest rate path. Third, we show that forecast errors are considerably larger for contracts with maturity dates further into the future. Thus, a consequence could be to use interest rate futures and surveys only for the near future (next few quarters).

The remainder of this paper is structured as follows: Section 2 gives an overview of the literature. Section 3 describes the institutional details of the LIBOR futures market and the SNB's monetary policy framework, while Section 4 introduces the notion of excess returns, term premium and forecast errors. Section 5 describes the dataset used and provides descriptive statistics. Section 6 presents the regressions analysis, while Section 7 provides robustness checks and a discussion of potential drawbacks of interest rate surveys. Finally, Section 8 concludes.

\section{Literature}

Our paper is related to the literature on the term structure of interest rates and the term premium. To understand the term structure of interest rates, the expectation hypothesis offers a very simple and intuitive concept by proposing that long-term interest rates reflect current and future expected short-term rates. However, there is considerable empirical evidence challenging the expectation hypothesis and it is generally accepted that long-term interest rates correspond to expected average short-term interest rates over the according maturity as well as a term premium. The term premium compensates investors for interest rate risks and may also reflect other factors such as supply and demand imbalances, liquidity considerations or flight to quality effects. As the term premium is unobservable it needs to be estimated. To do so, there exist a variety of methods such as no-arbitrage models or model-free approaches, see for example, Kim and Orphanides (2007) for an overview.

In this paper, we use the model-free approach to estimate the term premium in CHF forward rates. In this approach, interest rate surveys are used as a proxy for interest rate expectations, while interest rates based on financial market prices reflect interest rate expectations as well as a term premium. Several papers analyze the term premium in interest rate forward contracts. Among the first papers highlighting that forward rates can contain a term premium were Friedman (1979), Fama and Bliss (1987), and Froot (1989). The authors highlight that the difference between forward rates and ex-post realizations (excess returns) is not only capturing the term premium but also tests rational expectations, i.e., whether forecast errors are zero on average. Subsequently, several contributions and extensions were provided. Peacock (2004) finds evidence for the existence of a term premium in forward rates using sterling short-term rates and interest rate surveys, while Gameiro (2006) provides similar evidence for German 3-month interest rates. Piazzesi and Swanson (2008) show that excess returns in federal funds futures are positive on average and predictable by macroeconomic and financial market variables. Ferrero and Nobili (2009) extend the analysis and show that excess returns in the Euro area have similar properties and highlight that excess returns in U.S. dollar and Euro result predominantly due to forecast errors. Moreover, they show that the relationship between excess returns and macroeconomic variables is not stable over time and only significant for the United States. Ichiue and Yuyama (2009) show that, on average, positive excess returns mostly arise as market participants do not anticipate the declining trend in 
interest rates during the recent decades. Moreover, interest rate surveys have recently also been used to obtain model-free estimates of the U.S. dollar term premium for longer-term rates (Crump et al. 2016). Finally, there is a strain of policy work explaining potential reasons for the differences between federal fund futures and the dot plots by Federal Open Market Committee members. Among others, references are Kim and Tanaka (2016), Crump et al. (2014a), Crump et al. (2014b), Brodsky et al. (2016a), and Brodsky et al. (2016b).

Beside the model-free approach, there are a variety of term structure models estimating the term premium directly from the yield curve (for an overview see, for example, Kim and Orphanides (2007), Gibson et al. (2010) or Cohen et al. (2018)). Some of these models make use of survey data as additional model input to better pin down the future path of short rates to overcome estimation problems. For example, Kim and Orphanides (2012) argue that incorporating survey data into term structure models alleviates the difficulty of statistical inference about persistent variables as interest rates in short samples. With the existence of an effective lower bound, estimation challenges of term structure models even increase because it introduces non-linearities into the term structure model and estimation process. Recently, Priebsch (2017) for U.S. dollar interest rates and Geiger and Schupp (2018) for Euro interest rates incorporate survey data into a shadow rate model.

For CHF interest rates, the term structure literature is comparably small. Kugler (1996), Hsu et al. (1996), and Kugler (1988) reject the expectation hypothesis for short-term rates. Moreover, Kugler $(1996,1997)$ provide evidence for a time-varying term premium in shortterm rates. This result is confirmed by Gerlach-Kristen (2007) for long-term government bonds, while at the short-end of the yield curve the expectation hypothesis cannot be rejected. Furthermore, Gerlach-Kristen (2007) analyzes the relationship between the term structure and macroeconomic variables and finds that a steepening of the interest rate curve predicts an increase in economic activity. Söderlind (2010) estimates an affine yield curve model using interest rate options and illustrates that a surprise increase in the SNB's LIBOR target decreases the term premium in longer-term rates. More recently, apply the arbitrage-free Nelson-Siegel model developed by Christensen et al. (2011) for CHF government bonds and document a reduction in the term premium for long-term yields following the SNB's expansion of reserves in 2011, which they attribute to a socalled reserve-induced portfolio balance effect. Finally, Grisse and Schumacher (2018) do not specifically consider the term premium but analyze the transmission of changes in short-term to longer-term interest rates. They find an asymmetric relationship during the period when interest rates were at zero, while the asymmetry was reduced when interest rates were effectively negative.

\section{Institutional background}

\subsection{LIBOR futures}

\subsubsection{Definition}

Interest rate futures are standardized forward rate agreements. In an interest rate forward contract, counterparties agree today on the rate at which the buyer of the futures contract (lender) places a deposit with the seller (borrower) at a specific maturity date in the future. In $\mathrm{CHF}$ LIBOR futures, the underlying rate is the CHF 3-month LIBOR. LIBOR is a panel-based reference rate that provides an indication of the average rate at which LIBOR panel banks can obtain unsecured funding for a specific maturity and currency. ${ }^{3}$

\subsubsection{Trading motivation}

LIBOR futures can be used for hedging interest rate risks or to speculate on future interest rates (Veyrassat 2004). The buyer (seller) of a LIBOR futures contract profits if interest rates fall (rise), i.e., if the 3-month LIBOR fixing at maturity is below (above) the agreed rate in the LIBOR futures contract. Hence, the price determining factors of an interest rate futures contract are, on the one hand, the expectations regarding the underlying interest rate evolution and, on the other hand, the premium market participants are willing to pay for hedging interest rate risks or taking speculative positions.

\subsubsection{Conventions}

CHF LIBOR futures ${ }^{4}$ are traded on an electronic and anonymous trading platform offered by the Intercontinental Exchange (ICE). Trades can be initiated by entering a quote into the central order book and are concluded via an automatic matching algorithm. The official trading hours are from 7:30 a.m. to 6:00 p.m. London time. The quotation on the trading platform is 100.00 minus the forward interest rate. Thus, for example, a LIBOR futures contract with a price of 99.50 implies a forward interest rate of $0.50 \%$. LIBOR futures are traded with different pre-defined settlement dates. Settlement dates are International Monetary Market (IMM) dates: the third Wednesday of March, June, September, and December of each year. The last trading day for a specific LIBOR futures contract is two business days prior to its settlement date (i.e., IMM date). LIBOR futures are based on a CHF 1 million notional. Contracts are cash settled and the settlement price is the 3-month LIBOR at the last trading date. Trades are cleared through ICE Clear Europe. ICE Clear Europe acts as a central counterparty and guarantees the settlement of all trades concluded. 


\subsubsection{Usage}

LIBOR futures are available for trading for the next four years (i.e., the next 16 settlement dates). Most trading activity takes place for LIBOR futures contracts expiring within the next year (see Table 1) and the trading activity is roughly stable since 2005. As of year-end 2016, the open interest of CHF LIBOR futures was approximately CHF 220 billion (source: Bloomberg L.P.). Moreover, Swiss banks disclose a total amount of CHF 370 billion open interest in interest rate futures contracts across different currencies and products. ${ }^{5}$ Overall, LIBOR futures are a liquid trading instrument and no adjustment for a potential illiquidity premium is necessary, as is the case, for example, in the market for US Treasury Inflation-Protected Securities (Grishchenko and Huang 2013).

\subsection{SNB's monetary policy regimes}

During the sample period (1991-2016, see discussion in Section 5), the SNB used two different monetary policy frameworks. First, between 1991 and 1999, the SNB used a monetary targeting regime to achieve price stability. It was conducted by publishing a target growth rate for the seasonally adjusted monetary base. Second, up from 2000, the SNB implements monetary policy by steering short-term interest rates. The SNB's monetary policy reference interest rate is the 3-month CHF LIBOR for which a target range of usually $100 \mathrm{bps}$ is announced as the operational target. Typically, the SNB aims to keep the reference rate in the middle of the target range (Swiss National Bank 1999). Beginning at the end of 2008, the CHF experienced a significant appreciation in value in the wake of the financial crisis. The SNB fought the overvaluation of the CHF with an expansionary monetary policy. This included lowering interest rates, FX interventions (starting in March 2009) and implementing a minimum exchange rate of CHF 1.20 against the Euro as an additional operational target between September 2011 and January 2015. Since the discontinuation of the minimum exchange rate, the SNB applies a tiered remuneration system with a negative interest rate of $-0.75 \%$. In the tiered remuneration system, reserve holdings that exceed an individually defined threshold are remunerated at $-0.75 \%$, while reserves below this threshold are remunerated at $0 \%$.

Table 1 Trading activity

\begin{tabular}{llllllll}
\hline 1st & 2nd & 3rd & 4th & 5th & 6th & 7th & 8th \\
\hline 4826 & 5937 & 4482 & 3159 & 1765 & 1016 & 585 & 415
\end{tabular}

The table reports the average daily trading activity (number of trades) in CHF LIBOR futures. LIBOR futures are based on a CHF 1 million notional. Averages are reported for International Monetary Market (IMM) dates (columns) and are based on business days during the year 2016. IMM dates are the third Wednesday of March, June,

September, and December of each year

\section{Excess returns, term premium, and forecast errors}

The excess return is the difference between the interest rate implied by a LIBOR futures contract and the 3-month LIBOR fixing at the maturity of the futures contract (see, e.g., Piazzesi and Swanson (2008)). Excess returns are either the result of forecast errors or the term premium. The term premium reflects the markup that market participants are willing to pay for hedging or speculation. Forecast errors occur due to unexpected interest rate changes.

\subsection{Excess returns}

Formally, the excess return $\epsilon_{t}^{n}$ at time $t$ with corresponding maturity $n$ is defined as the LIBOR futures contract $Y_{t}^{n}$ traded at time $t$ with $n$ days to maturity minus the 3-month LIBOR fixing $R_{t+n}$ at time $t+n$.

$$
\epsilon_{t}^{n}=Y_{t}^{n}-R_{t+n}
$$

The excess return is positive (negative) if the 3-month LIBOR fixing at maturity of the futures contract $R_{t+n}$ is below (above) the LIBOR futures contract $Y_{t}^{n}$. Economically speaking, the buyer (seller) of the futures contract earns (pays) the excess return. ${ }^{6}$ Hence, a positive excess return corresponds to a cash flow from the futures seller to the buyer, and vice versa for a negative excess return.

\subsection{Term premium and forecast errors}

We decompose excess returns into the term premium and forecast errors. As a proxy for interest rate expectations, we use interest rate surveys $S_{t}^{n}$ of $n$ day forecasts conducted at time $t$. We assume that survey responses do not contain a term premium because they are not traded. Equation 2 formally illustrates the decomposition of excess returns into the two components.

$$
\epsilon_{t}^{n}=\underbrace{Y_{t}^{n}-S_{t}^{n}}_{\text {term premium }}+\underbrace{S_{t}^{n}-R_{t+n}}_{\text {forecast error }}
$$

The first term is the term premium, which is the difference between the LIBOR futures contract $Y_{t}^{n}$ and the interest rate survey $S_{t}^{n}$. The term premium can be interpreted as the markup that one side of the market (buyer or seller) is willing to pay to lock in a future interest rate. In the case of a positive (negative) term premium, sellers (buyers) have a higher demand to hedge against or speculate on increasing (decreasing) interest rates and are therefore willing to pay the term premium to the buyers (sellers). The second term in Eq. 2 represents the forecast error, which is the difference between the interest rate survey $S_{t}^{n}$ and the 3-month LIBOR fixing at the maturity of the futures contract $R_{t+n}$. 


\section{Data and descriptive statistics}

\subsection{Data}

\subsubsection{Survey data}

Interest rate survey data are obtained from Consensus Economics. ${ }^{7}$ Consensus Economics is a company specialized in preparing forecasts of macroeconomic and financial market indicators, based on individual forecaster predictions. The survey has a monthly frequency and is available from 1989 onwards. Survey participants are typically associated with financial institutions, mostly domestic and international banks. Each month, forecasters estimate what the CHF 3-month LIBOR will be at month's end 3 and 12 months later. Consensus Economics typically receives survey responses on the second Monday of each month (survey date). For the entire sample period, Consensus Economics reports the average value submitted by all survey participants while individual survey estimates are available from 1999 onwards. For this period, eight individual survey responses are available on average.

\subsubsection{LIBOR fixings and futures}

LIBOR fixings and LIBOR futures are obtained from Bloomberg L.P. and have a daily frequency. CHF LIBOR fixings started in 1989 and LIBOR futures have been available from March 1991 onwards. LIBOR futures are settled on IMM dates and thus have a nonconstant maturity. This contrasts Consensus surveys, which have constant maturities of 3 and 12 months. To make the two datasets comparable we compute LIBOR futures with maturities identical to Consensus surveys using spline interpolation (see also Table 2 for a description of the data transformation). Moreover, the frequency of LIBOR futures and fixings is reduced from daily to monthly using the survey date as reference.

\subsection{Descriptive statistics}

During the sample period, interest rates were declining from approximately 8 to $-0.75 \%$ (see Fig. 1 ). On average, the 3 -month LIBOR is $1.91 \%$, whereas LIBOR futures and interest rate survey, both with a 12-month maturity, are $2.17 \%$ and $2.19 \%$, respectively (see Table 3 panel A).

\subsubsection{Excess returns}

Table 3 panel B provides descriptive statistics of excess returns. Excess returns are positive, on average, for both maturities (3 and 12 months) and increase with the duration of the contract (ranging from 12 to $63 \mathrm{bps}$ ). Median excess returns are generally lower than average excess returns; hence, the distributions are skewed to the right. To test whether average excess returns are statistically significantly different from zero, we compute standard errors that are heteroscedasticity and autocorrelation consistent, using the Newey and West (1987) correction. ${ }^{8}$ For both maturities, excess returns are statistically significant.

\subsubsection{Term premium}

Table 3 panel $B$ shows that the average term premium is close to zero and not statistically significant for both maturities. The black bars in Figs. 2 and 3 illustrate the development of the term premium, which fluctuates in the range of $+/-100$ bps. The estimated term premium has several interesting empirical properties. First, the correlation between the 3-month and 12-month term premium is high, with a correlation coefficient of about 0.78 . Thus, we document considerable co-movements in the term premium across different maturities. Second, the term premium accounts for the bulk of the variation in LIBOR futures rates, which is illustrated in Fig. 4. Hence, the largest part of changes in LIBOR futures does not reflect a change in future expected short-term interest rates but a change in the term premium. Third, the average term premium for the two monetary policy periods are fairly similar and in line with the averages for the overall sample period. While for the period from 1991 until 1999, the average term premium is $-6 \mathrm{bps}(-8 \mathrm{bps})$ for the 3-month (12-month) maturity, the average term premium for the period from 2000 until 2017 is 0 bps (2 bps). Fourth, the magnitude of the estimated term premium is smaller for the period when the SNB steered short-term interest rates. While the standard deviation of the 3-month (12-month) term premium is 41 bps (57 bps) until 1999 it is 15 bps (30 bps) afterwards. Fifth, Figs. 2 and 3 show that the term premium has been persistently negative between 2010 and 2016, i.e., in a period with low and declining interest rates. By contrast, the

Table 2 Data preparation

\begin{tabular}{|c|c|c|c|c|c|c|}
\hline \multirow[b]{2}{*}{ Instrument } & \multicolumn{3}{|l|}{ Input data } & \multicolumn{3}{|l|}{ Final data } \\
\hline & Frequency & Availability & Maturity & Frequency & Availability & Maturity \\
\hline Survey data & Monthly & Dec. 89-Aug. 16 & In $3 \mathrm{M}$ and $12 \mathrm{M}$ (end of month) & Monthly & Mar. 91-Aug. 16 & In $3 \mathrm{M}$ and $12 \mathrm{M}$ (end of month) \\
\hline Libor futures & Daily & Mar. 91-Aug. 17 & IMM dates* & Monthly** & Mar. 91-Aug. 16 & In $3 \mathrm{M}$ and $12 \mathrm{M}$ (end of month) ${ }^{* * *}$ \\
\hline Libor 3M & Daily & Dec. 89-Aug. 17 & $3 M$ & Monthly & Mar. 91-Aug. 16 & $3 M$ \\
\hline
\end{tabular}

Table 2 describes the dataset and the transformation of the data. ${ }^{*}$ International Monetary Market (IMM) dates are the third Wednesday of March, June, September, and December of each year. ${ }^{* *}$ LIBOR futures as of the survey date are used. ${ }^{* *}$ Adjustment is performed via spline interpolation 


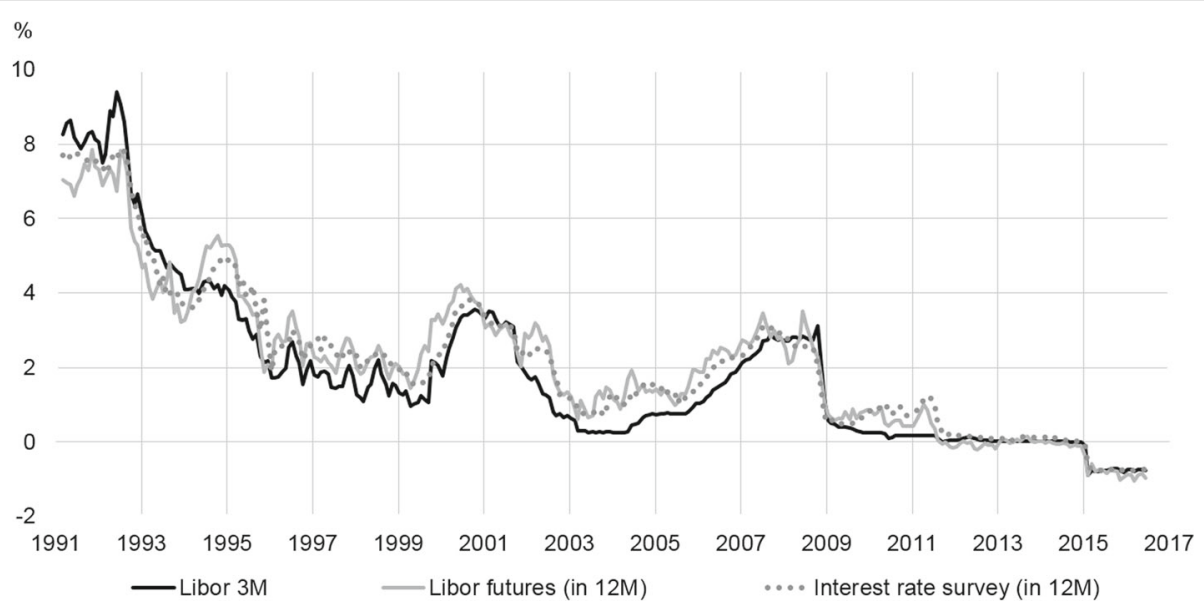

Fig. 1 Interest rate developments. The figure shows the development of the CHF 3-month LIBOR fixing (black line), the interest rate survey with an end of month maturity in 12 months (gray dotted line), and LIBOR futures with an end of month maturity in 12 months (gray line). The dataset contains monthly observations from March 1991 through August 2016

Table 3 Descriptive statistics

\begin{tabular}{|c|c|c|c|c|c|c|c|c|}
\hline & Unit & Mean & t stat & p50 & Min & Max & sd & Count \\
\hline \multicolumn{9}{|l|}{ Panel A: Interest rates } \\
\hline Libor $3 \mathrm{M}$ & $\%$ & 1.91 & & 1.34 & -0.90 & 9.41 & 2.27 & 306 \\
\hline Futures $3 \mathrm{M}$ & $\%$ & 1.92 & & 1.59 & -0.99 & 8.71 & 2.16 & 306 \\
\hline Futures $12 \mathrm{M}$ & $\%$ & 2.17 & & 2.04 & -1.06 & 7.86 & 2.02 & 306 \\
\hline Survey $3 \mathrm{M}$ & $\%$ & 1.94 & & 1.51 & -0.94 & 8.80 & 2.22 & 306 \\
\hline Survey $12 \mathrm{M}$ & $\%$ & 2.19 & & 2.04 & -0.79 & 7.88 & 2.05 & 306 \\
\hline \multicolumn{9}{|c|}{ Panel B: Excess returns and decomposition } \\
\hline Excess return $3 \mathrm{M}$ & $\mathrm{pp}$ & $0.12^{* *}$ & 2.55 & 0.04 & -2.00 & 2.34 & 0.48 & 306 \\
\hline Excess return $12 \mathrm{M}$ & $\mathrm{pp}$ & $0.63^{* * *}$ & 3.89 & 0.56 & -2.57 & 3.56 & 1.02 & 306 \\
\hline Term premium 3M & $\mathrm{pp}$ & -0.02 & -0.90 & -0.03 & -1.39 & 0.88 & 0.27 & 306 \\
\hline Term premium $12 \mathrm{M}$ & $\mathrm{pp}$ & -0.02 & -0.30 & -0.05 & -1.91 & 1.29 & 0.41 & 306 \\
\hline Forecast error 3M & $\mathrm{pp}$ & $0.14^{* * *}$ & 2.83 & 0.06 & -1.60 & 2.42 & 0.50 & 306 \\
\hline Forecast error $12 \mathrm{M}$ & $\mathrm{pp}$ & $0.64 * * *$ & 3.86 & 0.53 & -1.88 & 3.28 & 1.00 & 306 \\
\hline \multicolumn{9}{|c|}{ Panel C: Explanatory variables } \\
\hline dispersion $_{3 M}$ & $\mathrm{pp}$ & 0.13 & & 0.12 & 0.02 & 0.51 & 0.08 & 219 \\
\hline dispersion $_{12 M}$ & $\mathrm{pp}$ & 0.27 & & 0.27 & 0.03 & 0.74 & 0.13 & 219 \\
\hline $\operatorname{garch}_{3 M}$ & $\mathrm{pp}$ & 1.07 & & 1.02 & 0.27 & 3.37 & 0.60 & 306 \\
\hline $\operatorname{garch}_{12 M}$ & $\mathrm{pp}$ & 1.54 & & 1.33 & 0.39 & 4.10 & 0.80 & 306 \\
\hline VIX & $\mathrm{pp}$ & 19.67 & & 17.63 & 10.64 & 62.47 & 8.07 & 306 \\
\hline$\Delta \mathrm{BCl}$ & index & 0.01 & & 0.04 & -2.55 & 1.92 & 0.63 & 306 \\
\hline$\Delta$ Libor $_{3 M}$ & $\mathrm{pp}$ & -0.03 & & 0.00 & -1.19 & 1.19 & 0.24 & 306 \\
\hline$\Delta \mathrm{CHF}$ real & index & 0.00 & & 0.00 & -0.10 & 0.08 & 0.02 & 306 \\
\hline
\end{tabular}

The table provides descriptive statistics for interest rates (panel A), excess returns, term premiums, forecast errors (panel B), and independent variables used in the regression analysis (panel C). The statistical significance of mean values for Panel B (column 3) is based on t-statistics (column 4). Heteroscedasticity and autocorrelation robust t-statistics are reported, using the Newey and West (1987) correction. The number of lags used equals the length of the contract (number of months). ${ }^{* * *}$, ${ }^{* *}$, and ${ }^{*}$ denote statistical significance (two-tailed) at the 1\%,5\%, and 10\% significance levels, respectively. The dataset contains monthly observations from March 1991 through August 2016 


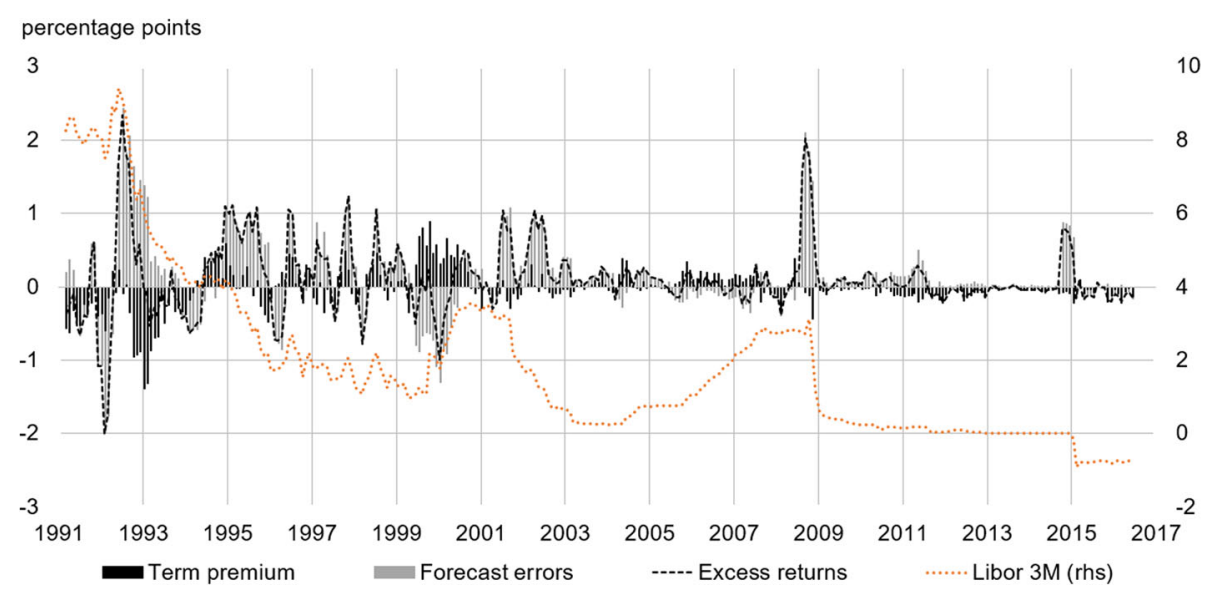

Fig. 2 Decomposition of excess returns (3-month maturity). The figure shows the development of excess returns with an end of month maturity in 3 months (black dashed line) and its decomposition. The term premium is depicted in black bars, and forecast errors are depicted in gray bars. The dataset contains monthly observations for LIBOR futures and interest rate surveys from March 1991 through August 2016

term premium was positive and persistent between 1999 and 2001 and between 2005 and 2007, both periods of increasing interest rates.

\subsubsection{Forecast errors}

Table 3 panel B shows that forecast errors are positive and statistically significant for both maturities and account for the largest part of excess returns. The development of forecast errors over the sample period is illustrated in Figs. 2 and 3. The figures reveal that market participants have been surprised by unexpected economic downturns and corresponding interest rate declines. For example, the interest rate cuts during the financial crisis of 2008 coincide with significant positive forecast errors, indicating that most market participants did not expect these events. Moreover, also the beginning of the sample period in 1991, characterized by high inflation and a pronounced weakening of economic activity, coincides with large forecast errors as well. In the very long run, average forecast errors could be expected not to be statistically significant, if expectations are rational. However, there are reasons why forecast errors may be persistently positive in our sample period (Ichiue and Yuyama 2009). First, although we have observations for the past 25 years, interest rates are generally declining, and thus, market participants could be surprised negatively when not adapting their expectations to the permanent decline. Second, in our sample period, interest rate hikes are fairly continuous and accompanied by corresponding forward guidance, in particular between 2005 and 2008 (see, e.g., SNB monetary policy assessment of June 2006), whereas interest rate cuts are rather abrupt and unanticipated.

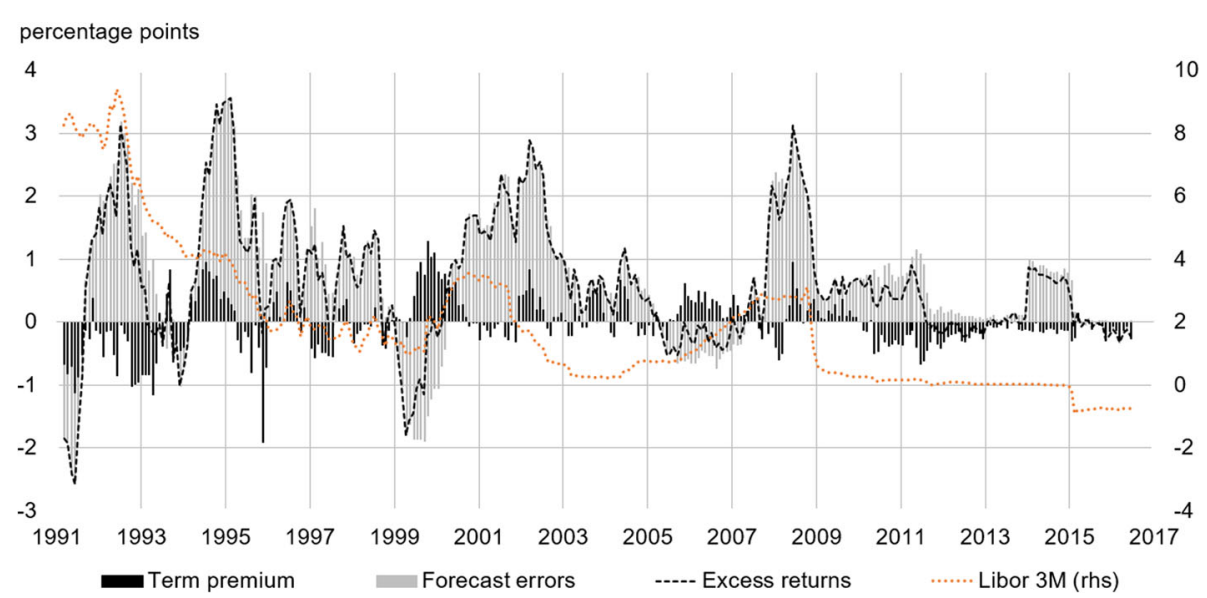

Fig. 3 Decomposition of excess returns (12-month maturity). The figure shows the development of excess returns with an end of month maturity in 12 months (black dashed line) and its decomposition. The term premium is depicted in black bars, and forecast errors are depicted in gray bars. The dataset contains monthly observations for LIBOR futures and interest rate surveys from March 1991 through August 2016 


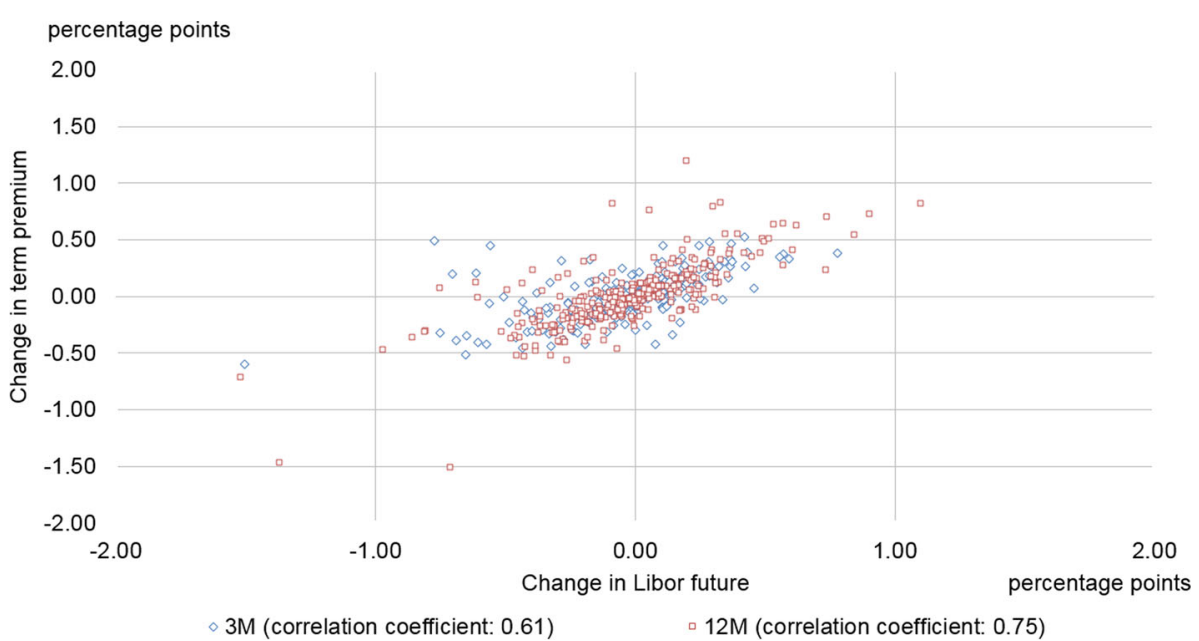

Fig. 4 Correlation of LIBOR futures and term premium. The figure shows a scatterplot of monthly changes in LIBOR futures and monthly changes in the term premium for the 3-month and the 12-month maturity

\section{Regression analysis}

As outlined by Kim and Orphanides (2007), the compensation demanded by investors to bear interest rate risk depends on the amount of risk as well as the price of that risk present at a certain point in time. For instance, the degree of uncertainty about the interest rate path might determine the potential amount of risks investors need to bear, while investors' risk-appetite might, for example, differ during the business cycle.

\subsection{Uncertainty and the term premium}

In this subsection, we study the link between the term premium and uncertainty, in particular interest rate uncertainty. One might expect uncertainty to increase the compensation required for bearing risks, as investors' ability to anticipate future outcomes declines. As the term premium can have positive as well as negative values, we are interested in a potential link between uncertainty and the magnitude of the term premium, regardless of whether it is positive or negative. We expect that in periods of greater uncertainty, the size of the absolute term premium in CHF LIBOR futures to be higher (see, e.g., Wright (2011) or Kim and Tanaka (2016)). To test this hypothesis, we employ a measure of general financial market uncertainty as well as two specific indicators for interest rate uncertainty. ${ }^{9}$ As indicator for general financial market uncertainty we use the Chicago Board Options Exchange Volatility Index (VIX). The first interest rate uncertainty measure we use is a volatility indicator for CHF LIBOR futures ("realized uncertainty"). To approximate the volatility of CHF LIBOR futures, we use a Generalized Autoregressive Conditional Heteroscedasticity $(\mathrm{GARCH})$ model, which incorporates the fact that a negative interest rate shock has a higher impact on the conditional volatility than a positive shock of the same magnitude, the so-called APARCH (Asymmetric Power Autoregressive Conditional Heteroscedasticity) by Ding et al. (1993). The model is described as

$$
\sigma_{t}^{\delta}=\omega+\alpha\left(\Delta Y_{t-1}-\gamma \Delta Y_{t-1}^{n}\right)^{\delta}+\beta \sigma_{t-1}^{\delta},
$$

where $\sigma_{t}$ denotes the conditional volatility at time $t$ and $\Delta Y_{t}$ lagged close-to-close changes in 3M CHF LIBOR futures. ${ }^{10}$ The second interest rate uncertainty measure we use is the standard deviation of Consensus survey responses ("expected uncertainty"). The standard deviation of survey responses ( $s_{t}$, see Eq. 4 ) is a good measure of the uncertainty of professional forecasters (Zarnowitz and Lambros 1987), however, it is only available from June 1998 onwards.

$$
s_{t}=\sqrt{\frac{1}{N} \sum_{i=1}^{N}\left(x_{i}-x\right)^{2}},
$$

To test the hypothesis we conduct two different regression specifications. First, we regress the absolute term premium $\left(\left|r_{t}\right|\right)$ on the respective measure of uncertainty $\left(u_{t}\right)$, see Eq. 5. Second, we differentiate between positive and negative values for the term premium and regress these on our uncertainty indicators, see Eq. $6 .^{11}$ For both approaches, the regression analysis is conducted separately for the 3- and 12-month maturity and we apply heteroscedasticity- and autocorrelation consistent standard errors, using the Newey and West (1987) correction. All variables used are described in Table 4.

$$
\begin{aligned}
& \left|r_{t}\right|=\beta_{0}+\beta_{1} u_{t}+\epsilon_{t} \\
& r_{t}^{\text {pos. } / \text { neg. }}=\beta_{0}+\beta_{1} u_{t}+\epsilon_{t}
\end{aligned}
$$


Table 4 Description of regression variables

\begin{tabular}{lll}
\hline Name & Unit & Abbreviation \\
\hline Risk premium & $\mathrm{pp}$ & $r$ \\
Absolute risk premium & $\mathrm{pp}$ & $|r|$ \\
Realized uncertainty (based on futures) & $\mathrm{pp}$ & garch \\
Expected uncertainty (based on survey) & $\mathrm{pp}$ & dispersion \\
CBOE volatility index & index & $\mathrm{VIX}$ \\
$\Delta$ Business cycle index & index & $\Delta \mathrm{BCl}$ \\
$\Delta$ 3-month Libor & $\mathrm{pp}$ & $\Delta$ Libor $_{3 M}$ \\
$\Delta$ Real Swiss franc index & index & $\Delta \mathrm{CHF}$ real \\
\hline
\end{tabular}

The regression results using the absolute term premium are illustrated in Table 5 and provide the following insights. First, we find a positive and statistically significant relationship between the volatility of LIBOR futures and the absolute term premium (columns (1) and (2)). In terms of economic magnitude, the results indicate that a 1 bps higher standard deviation of LIBOR futures results in a roughly $0.2 \mathrm{bps}$ larger absolute term premium (for both maturities). Second, columns (3) and (4) illustrate that the regression coefficients are also positive and statistically significant when using the expected uncertainty measure, i.e., the standard deviation of survey responses. In terms of economic magnitude, a 1 bps higher expected uncertainty goes along with a $0.5 \mathrm{bps}$ larger absolute term premium for the 3-month and $0.4 \mathrm{bps}$ for the 12-month maturity. Third, columns (5) and (6) illustrate that the regression coefficients are close to zero and statistically not significant for the VIX. These findings are consistent with the findings from our second approach, where we conduct separate regressions for positive and negative values of the term premium (see Table 6). The positive (negative) coefficients for positive (negative) values of the term premium indicate an increase (decrease) in the term premium if interest rate uncertainty increases. Again, the coefficients for the VIX are not statistically significant. Consequently, the results provide evidence that the size of the absolute term premium is affected by expected and realized interest rate uncertainty but not affected by the general uncertainty sentiment in financial markets.

\subsection{Economic variables and the term premium}

In this subsection, we analyze the link between different economic variables and the term premium. In particular, we are interested whether the CHF forward term premium is affected by the Swiss business cycle, interest rate movements and the value of the Swiss franc against major other currencies.

First, we study the relationship between the business cycle and the term premium. Despite the extensive literature, the relationship between these variables is not entirely clear. On the one hand, there are theoretical models indicating that the term premium should be

Table 5 Uncertainty and the size of the absolute term premium

\begin{tabular}{|c|c|c|c|c|c|c|}
\hline & (1) & $(2)$ & (3) & (4) & (5) & (6) \\
\hline & $\left|r_{3 M}\right|$ & $\left|r_{12 M}\right|$ & $\left|r_{3 M}\right|$ & $\left|r_{12 M}\right|$ & $\left|r_{3 M}\right|$ & $\left|r_{12 M}\right|$ \\
\hline \multirow[t]{2}{*}{ Constant } & -0.05 & 0.04 & $0.06^{* * *}$ & $0.14^{* * *}$ & $0.22^{* * *}$ & $0.36^{* * *}$ \\
\hline & $(0.03)$ & $(0.04)$ & $(0.02)$ & $(0.04)$ & $(0.05)$ & $(0.07)$ \\
\hline \multirow[t]{2}{*}{ VIX } & & & & & -0.00 & -0.00 \\
\hline & & & & & $(0.00)$ & $(0.00)$ \\
\hline \multirow[t]{2}{*}{ dispersion $_{12 M}$} & & & & $0.39^{* * *}$ & & \\
\hline & & & & $(0.13)$ & & \\
\hline \multirow[t]{2}{*}{ dispersion $_{3 M}$} & & & $0.49^{* *}$ & & & \\
\hline & & & $(0.19)$ & & & \\
\hline \multirow[t]{2}{*}{$\operatorname{garch}_{12 M}$} & & $0.17^{* * *}$ & & & & \\
\hline & & $(0.03)$ & & & & \\
\hline \multirow[t]{2}{*}{$\operatorname{garch}_{3 M}$} & $0.21^{* * *}$ & & & & & \\
\hline & $(0.04)$ & & & & & \\
\hline Adjusted $R^{2}$ & 0.37 & 0.25 & 0.07 & 0.05 & 0 & 0 \\
\hline Observations & 306 & 306 & 219 & 219 & 306 & 306 \\
\hline
\end{tabular}




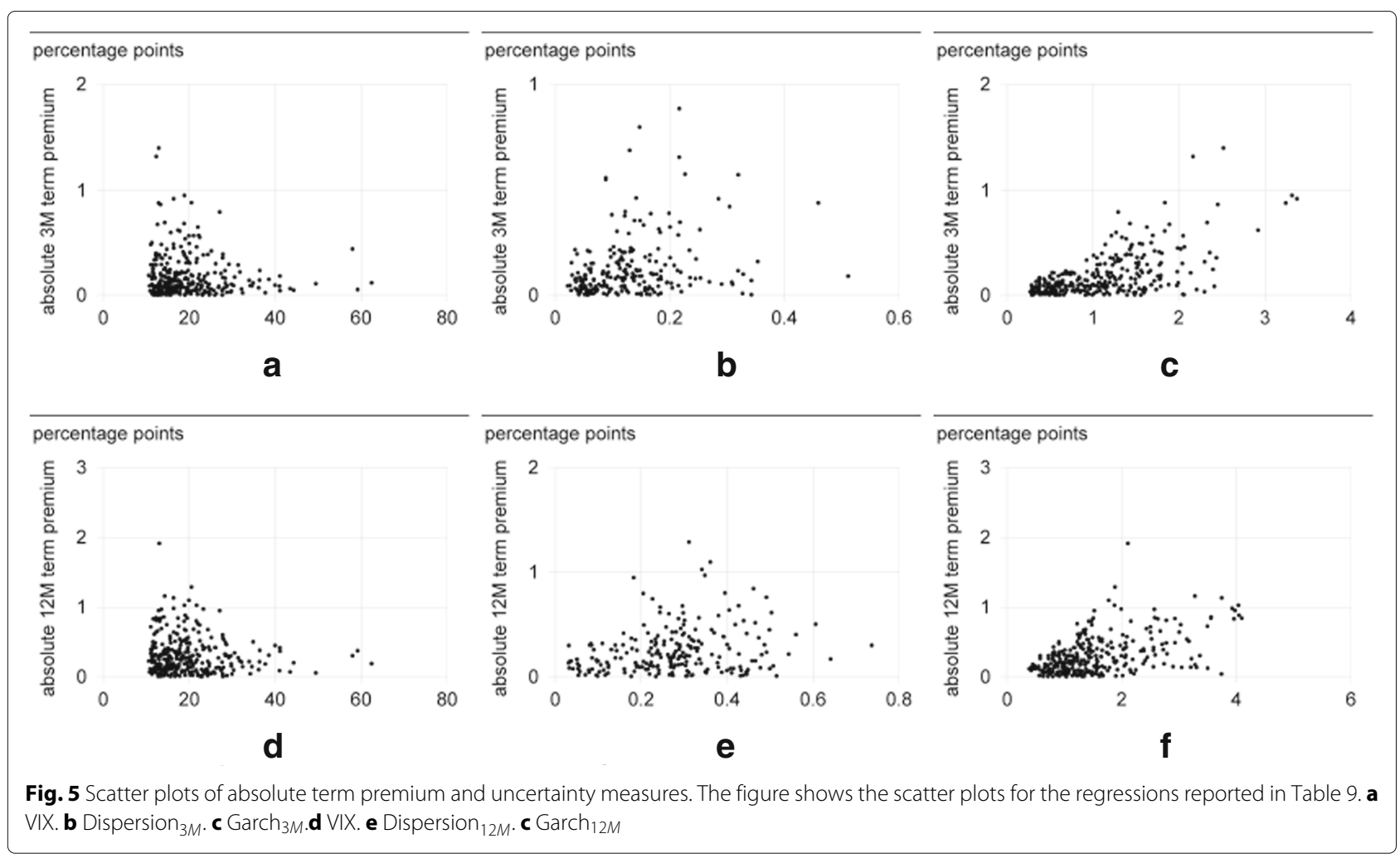

countercyclical as the investors are more risk-averse during an economic downturn and thus require a higher compensation for risks. On the other hand, investors may require a higher compensation in an economic boom, when interest rate hikes occur regularly (see discussion in Gameiro (2006)). Empirically, for example, Piazzesi and Swanson (2008) provide evidence that excess returns are countercyclical, while Ferrero and Nobili (2009) proved evidence that this relationship is not stable over time and only significant for the United States while for the Eurozone no such relationship exists. To identify this relationship for CHF forward rates, we use the Swiss business cycle index (BCI) as constructed by Galli (2018), which captures current economic conditions in Switzerland on a monthly frequency. ${ }^{12}$

Second, we analyze whether changes in the term premium in CHF LIBOR futures are correlated with current short-term interest rate movements. This could, for example, result because market participants assess interest rate risks to be cyclical, i.e., they price in a hiking cycle the risk of further increasing interest rates higher and vice versa when rates decline. This would suggest, that in an environment of increasing (decreasing) interest rates, the term premium is increasing (decreasing). To measure changes in short-term interest rates, we use first differences of the CHF 3-month LIBOR.

Third, Switzerland is a small and open economy, and the exchange rate plays an important role. Consequently, we test whether the term premium in CHF LIBOR futures is affected by the value of the CHF. Such a relationship could be the case due to real economic activities but may also result from speculative flows. As a measure of the strength of the CHF, we use the real effective CHF index (see Müller (2017)). We expect that a stronger CHF correlates with a lower term premium, as market participants may expect the SNB to decrease interest rates in periods of CHF strength.

The relationship between economic variables and the term premium is assessed on first differences by regressing changes in the term premium $\left(\Delta r_{t}\right)$ on changes in the different independent variables $\left(\Delta x_{t}\right)$ on a univariate and multivariate basis (see Eq. 7). Again, the regression analysis is conducted separately for the 3-and 12-month maturity.

$$
r_{t}=\beta_{0}+\sum_{n=1}^{N} \beta_{n} \Delta x_{t, n}+\epsilon_{t}
$$

The regression results are illustrated in Table $7 \mathrm{a}$. Columns (1)-(6) illustrate the univariate regression results, while columns (7) and (8) depict the multivariate regression results. The coefficients for changes in the business cycle are positive and statistically significant. Consequently, our analysis shows that in Switzerland the term premium is increasing (decreasing) in an economic upturn (downturn). The regression coefficient of 0.08 is 
Table 6 Uncertainty and the size of the absolute term premium for positive and negative values

\begin{tabular}{|c|c|c|c|c|c|c|}
\hline & (1) & (2) & (3) & (4) & (5) & (6) \\
\hline & $r_{3 M}$ & $r_{12 M}$ & $r_{3 M}$ & $r_{12 M}$ & $r_{3 M}$ & $r_{12 M}$ \\
\hline \multicolumn{7}{|c|}{ (a) For positive values of the term premium } \\
\hline \multirow[t]{2}{*}{ Constant } & 0.01 & 0.04 & 0.05 & 0.15 & $0.15^{* *}$ & $0.38^{* * *}$ \\
\hline & $(0.04)$ & $(0.07)$ & $(0.06)$ & $(0.1)$ & $(0.06)$ & $(0.08)$ \\
\hline \multirow[t]{2}{*}{ VIX } & & & & & -0.00 & -0.00 \\
\hline & & & & & $(0.00)$ & $(0.00)$ \\
\hline \multirow[t]{2}{*}{ dispersion $_{12 M}$} & & & & $0.5^{* *}$ & & \\
\hline & & & & $(0.23)$ & & \\
\hline \multirow[t]{2}{*}{ dispersion $_{3 M}$} & & & $0.93^{* *}$ & & & \\
\hline & & & $(0.46)$ & & & \\
\hline \multirow[t]{2}{*}{$\operatorname{garch}_{12 \mathrm{M}}$} & & $0.19^{* * *}$ & & & & \\
\hline & & $(0.05)$ & & & & \\
\hline \multirow[t]{2}{*}{ garch $_{3 M}$} & $0.16^{* * *}$ & & & & & \\
\hline & $(0.04)$ & & & & & \\
\hline Adjusted $R^{2}$ & 0.17 & 0.15 & 0.09 & 0.03 & 0 & 0 \\
\hline Observations & 123 & 134 & 87 & 102 & 123 & 134 \\
\hline \multicolumn{7}{|c|}{ (b) For negative values of the term premium } \\
\hline \multirow[t]{2}{*}{ Constant } & $0.07^{*}$ & -0.03 & $-0.06^{* * *}$ & $-0.16^{* * *}$ & $-0.24^{* * *}$ & $-0.35^{* * *}$ \\
\hline & $(0.04)$ & $(0.04)$ & $(0.01)$ & $(0.03)$ & $(0.08)$ & $(0.12)$ \\
\hline \multirow[t]{2}{*}{ VIX } & & & & & -0.00 & -0.00 \\
\hline & & & & & $(0.00)$ & $(0.00)$ \\
\hline \multirow[t]{2}{*}{ dispersion $_{12 M}$} & & & & -0.12 & & \\
\hline & & & & $(0.14)$ & & \\
\hline \multirow[t]{2}{*}{ dispersion $_{3 M}$} & & & $-0.23^{* *}$ & & & \\
\hline & & & $(0.1)$ & & & \\
\hline \multirow[t]{2}{*}{ garch $_{12 M}$} & & $-0.17^{* * *}$ & & & & \\
\hline & & $(0.03)$ & & & & \\
\hline \multirow[t]{2}{*}{ garch $_{3 M}$} & $-0.23^{* * *}$ & & & & & \\
\hline & $(0.05)$ & & & & & \\
\hline Adjusted $R^{2}$ & 0.48 & 0.34 & 0.06 & 0 & 0.01 & 0 \\
\hline Observations & 183 & 172 & 132 & 117 & 183 & 172 \\
\hline
\end{tabular}

The table shows the regression results for uncertainty measures and the size of the absolute term premium for positive and negative values of the risk premium. The uncertainty measure for futures is based on the GARCH model by Ding et al. (1993). The standard deviation of survey estimates is the standard deviation of all survey estimates for a specific survey date. The dataset contains monthly observations. Note that the standard deviation of survey estimates is not available for the entire sample period but only from June 1998 onwards, which reduces the number of observations in our regression analysis. Heteroscedasticity- and autocorrelation-consistent standard errors (in parentheses) are applied, using the Newey and West (1987) correction. The number of lags used equals the length of the contract (number of months). ${ }^{* * *}$,*, and * denote statistical significance (two-tailed) at the 1\%,5\%, and $10 \%$ significance levels, respectively

identical for the univariate and the multivariate regression for the 12-month maturity. In case of the 3-month maturity, it is slightly declining from 0.05 for the univariate to 0.03 for the multivariate regression. In terms of economic magnitude, the results indicate that a one standard deviation increase in the business cycle index is associated with a roughly 0.1 standard deviation increase in the term premium. The coefficients for changes in 3-month LIBOR rates are also positive and statistically significant in the univariate and multivariate regressions and for both maturities. For all regression specifications, the change in the term premium is estimated to be about $0.3 \mathrm{bps}$ if the 3-month LIBOR increases by 1 bps. This provides evidence that market participants pro-cyclically hedge interest rate risks or speculate on interest rate movements. Finally, the regression analysis provides no evidence that changes in the term premium are influenced by changes in the real effective CHF index. Neither the univariate 
Table 7 Economic variables and the term premium

\begin{tabular}{|c|c|c|c|c|c|c|c|c|}
\hline & (1) & (2) & (3) & (4) & (5) & (6) & (7) & (8) \\
\hline & $\Delta r_{3 M}$ & $\Delta r_{12 M}$ & $\Delta r_{3 M}$ & $\Delta r_{12 M}$ & $\Delta r_{3 M}$ & $\Delta r_{12 M}$ & $\Delta r_{3 M}$ & $\Delta r_{12 M}$ \\
\hline \multicolumn{9}{|c|}{ (a) From March 1991 through August 2016} \\
\hline \multirow[t]{2}{*}{ Constant } & 0 & 0 & 0.01 & 0.01 & 0 & 0 & 0.01 & 0.01 \\
\hline & $(0.01)$ & $(0.01)$ & $(0.01)$ & $(0.01)$ & $(0.01)$ & $(0.01)$ & $(0.01)$ & $(0.01)$ \\
\hline \multirow[t]{2}{*}{$\Delta \mathrm{BCl}$} & $0.05^{* * *}$ & $0.08^{* * *}$ & & & & & $0.03^{* *}$ & $0.08^{* *}$ \\
\hline & $(0.01)$ & $(0.03)$ & & & & & $(0.02)$ & $(0.03)$ \\
\hline \multirow[t]{2}{*}{$\Delta$ Libor $_{3 M}$} & & & $0.31^{* * *}$ & $0.29^{* * *}$ & & & $0.29^{* * *}$ & $0.26^{* * *}$ \\
\hline & & & $(0.08)$ & $(0.08)$ & & & $(0.08)$ & $(0.07)$ \\
\hline \multirow[t]{2}{*}{$\Delta \mathrm{CHF}$ real } & & & & & -0.82 & -1.12 & 0.23 & 0.78 \\
\hline & & & & & $(0.67)$ & $(0.75)$ & $(0.57)$ & $(0.92)$ \\
\hline Adjusted $R^{2}$ & 0.02 & 0.03 & 0.16 & 0.05 & 0 & 0 & 0.16 & 0.07 \\
\hline Observations & 305 & 305 & 305 & 305 & 305 & 305 & 305 & 305 \\
\hline \multicolumn{9}{|c|}{ (b) From March 1991 through December 1999} \\
\hline \multirow[t]{2}{*}{ Constant } & 0 & 0.01 & $0.04^{* *}$ & $0.04^{*}$ & 0.01 & 0.02 & $0.03^{* *}$ & $0.04^{*}$ \\
\hline & $(0.02)$ & $(0.02)$ & $(0.02)$ & $(0.02)$ & $(0.02)$ & $(0.02)$ & $(0.02)$ & $(0.02)$ \\
\hline \multirow[t]{2}{*}{$\Delta \mathrm{BCl}$} & $0.11^{* * *}$ & $0.11^{*}$ & & & & & 0.05 & 0.09 \\
\hline & $(0.04)$ & $(0.06)$ & & & & & $(0.04)$ & $(0.07)$ \\
\hline \multirow[t]{2}{*}{$\Delta L_{i b o r}{ }_{3 M}$} & & & $0.47^{* * *}$ & $0.42^{* * *}$ & & & $0.45^{* * *}$ & $0.4^{* * *}$ \\
\hline & & & $(0.05)$ & $(0.11)$ & & & $(0.05)$ & $(0.09)$ \\
\hline \multirow[t]{2}{*}{$\Delta \mathrm{CHF}$ real } & & & & & -2.19 & 0.37 & 0.12 & $3.43^{*}$ \\
\hline & & & & & $(1.95)$ & (1.9) & $(1.56)$ & $(1.98)$ \\
\hline Adjusted $R^{2}$ & 0.04 & 0.01 & 0.35 & 0.1 & 0 & -0.01 & 0.35 & 0.1 \\
\hline Observations & 105 & 105 & 105 & 105 & 105 & 105 & 105 & 105 \\
\hline \multicolumn{9}{|c|}{ (c) From January 2000 through August 2016} \\
\hline \multirow[t]{2}{*}{ Constant } & 0 & 0 & 0 & 0 & 0 & 0 & 0 & 0 \\
\hline & $(0.01)$ & $(0.01)$ & $(0.01)$ & $(0.01)$ & $(0.01)$ & $(0.01)$ & $(0.01)$ & $(0.01)$ \\
\hline \multirow[t]{2}{*}{$\Delta \mathrm{BCl}$} & $0.02 * *$ & $0.07^{* *}$ & & & & & $0.03^{*}$ & $0.07^{* *}$ \\
\hline & $(0.01)$ & $(0.03)$ & & & & & $(0.01)$ & $(0.03)$ \\
\hline \multirow[t]{2}{*}{$\Delta$ Libor $_{3 M}$} & & & -0.02 & 0.03 & & & -0.03 & -0.01 \\
\hline & & & $(0.08)$ & $(0.06)$ & & & $(0.08)$ & $(0.06)$ \\
\hline \multirow[t]{2}{*}{$\Delta \mathrm{CHF}$ real } & & & & & -0.27 & $-1.63^{* *}$ & 0.24 & -0.23 \\
\hline & & & & & $(0.43)$ & $(0.75)$ & $(0.57)$ & $(0.82)$ \\
\hline Adjusted $R^{2}$ & 0.01 & 0.06 & 0 & 0 & 0 & 0.01 & 0 & 0.05 \\
\hline Observations & 199 & 199 & 199 & 199 & 199 & 199 & 199 & 199 \\
\hline
\end{tabular}

The table shows the regression results for economic variables and the term premium (see Fig. 6 for a graphical illustration of the relationships). All variables are in first differences. The dataset contains monthly observations. Heteroscedasticity- and autocorrelation-consistent standard errors (in parentheses) are applied, using the Newey and West (1987) correction. The number of lags used equals the length of the contract (number of months). ***, **, and * denote statistical significance (two-tailed) at the $1 \%, 5 \%$, and $10 \%$ significance levels, respectively

nor the multivariate regression coefficients are statistically significant.

\section{Robustness}

7.1 Critical reflections on the use of survey data The advantage of directly using interest rate surveys is that they enable us to disentangle forecast errors from the term premium in a relatively simple way. Additionally, the model-free approach does not impose assumptions on the existence of the effective lower bound, as this is reflected in the expectations of survey participants. ${ }^{13}$ However, this approach also implies that our findings crucially rely on the assumption that surveys reflect "true" interest rate expectations. We discuss some issues which 


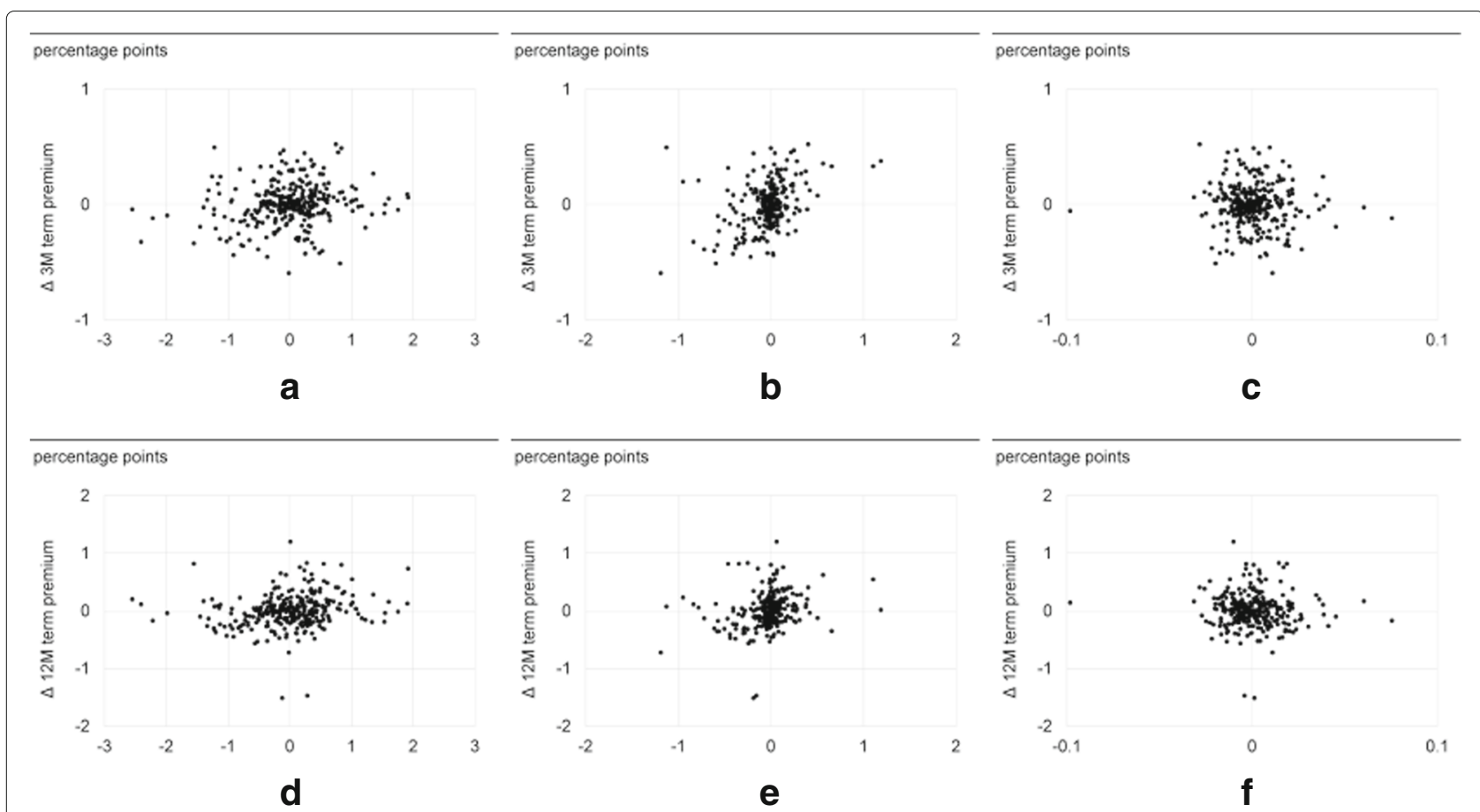

Fig. 6 Scatter plots of first differences for term premium and economic variables. The figure shows the scatter plots for the regressions reported in Table 9. a $\triangle \mathrm{BCl}$. b $\triangle$ Libor $_{3 M}$. $\mathbf{c} \triangle \mathrm{CHF}$ real. $\mathbf{d} \triangle \mathrm{BCl}$. b $\triangle$ Libor $_{3 M}$. $\mathbf{c} \triangle \mathrm{CHF}$ real

might be associated with survey data. First, there may be different outcomes conditional on the formulation or ordering of the survey questions. For instance, de Bruin et al. (2012) show that different ways of wording inflation, e.g., "prices you pay" or "inflation", leads to different inflation forecasts. Second, in interest rate surveys the survey participants' interpretation of short-term rates might differ. This may be understood differently by respondents, e.g., overnight rate or 3-month LIBOR. Third, it might be that the mean, median or mode is reported by the forecasters as many surveys do not ask for a specific statistic. Fourth, assuming that the survey even asks for the density forecast, consistency across point estimate and density forecast might not be given. Phillot and Rosenblatt-Wisch (2018) can show that forecast inconsistencies change significantly depending on whether the point forecast or the density forecast is asked. Fifth, there might be a potential variation in the information available to survey participants and the point in time at which they submit their answers. Therefore, answers might differ conditional on the individual information set. A final drawback might be that forecasters may use LIBOR futures to derive their interest rate estimates, which would lead to an endogeneity issue.

\subsection{Consistency across survey providers}

To ensure that the decomposition of excess returns is robust with regard to the source of the survey, we use alternative surveys from Bloomberg L.P. and KOF Consensus Forecasts, which are available in a similar manner as Consensus surveys. ${ }^{14}$ Figure 7 compares different interest rate surveys. For the available sample period of those surveys (2009 through 2016) the differences between the different interest rate surveys are rather small. Moreover, all interest rate surveys are considerably higher than LIBOR futures, indicating a negative term premium. In numbers, for the period 2009 until 2016 the average term premium based on the Consensus survey is $-17 \mathrm{bps}$; for the Bloomberg L.P. survey, it is $-13 \mathrm{bps}$; and for the $\mathrm{KOF}$ Consensus Forecasts, it is -18 bps. Hence, we conclude that the decomposition of excess returns is robust with regard to the choice of survey source.

\subsection{Interpolation of LIBOR futures}

To obtain LIBOR futures with a constant maturity of 3 and 12 months, we use a spline interpolation as of the survey date. To ensure that our findings are robust with regard to the interpolation method, we also apply a polynomial interpolation method. Table 8 illustrates that the two techniques result in virtually identical estimations. On average, the absolute difference between the polynomial and the spline estimation is only $0.2 \mathrm{bps}$ for the 3 - and the 12-month maturity. Thus, we conclude that our findings are robust with regard to the interpolation method. 


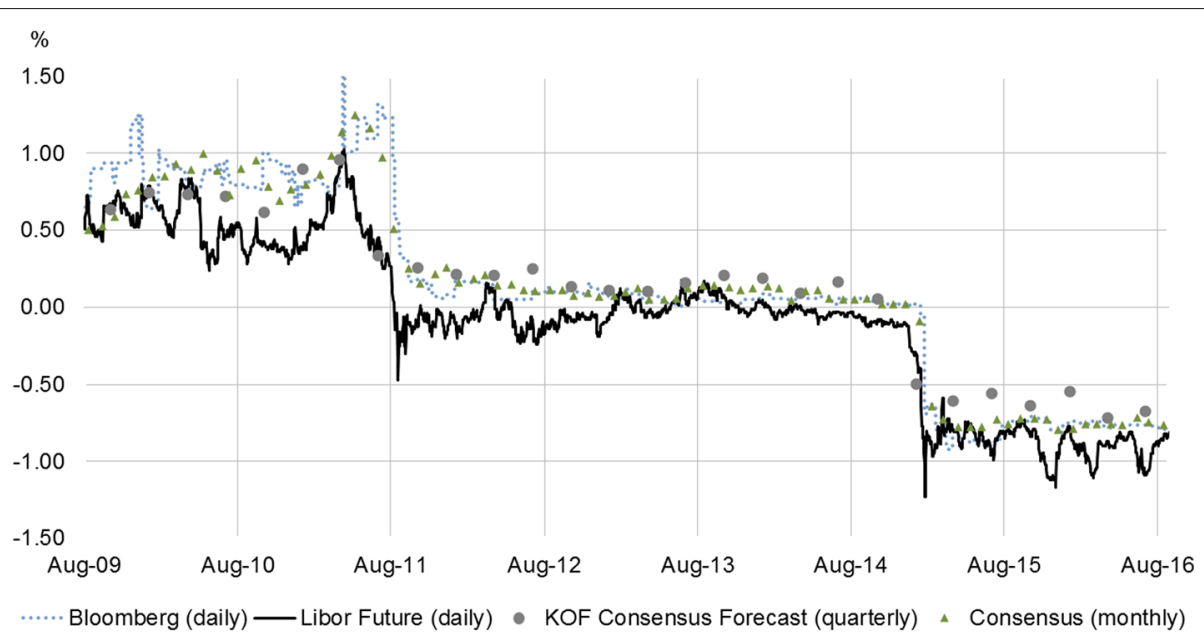

Fig. 7 Comparison of interest rate surveys (12-month maturity). The figure compares different interest rate surveys with LIBOR futures (black line). The Bloomberg L.P. survey is depicted by the blue dotted line, the Consensus survey by the green triangles, and the KOF Consensus Forecast by the gray circles

\subsection{Comparison with term structure model}

In Fig. 8, we compare our model-free estimation of the CHF term premium with the term premium obtained from an Arbitrage-Free Nelson-Siegel term structure model as developed by Christensen et al. (2011) and applied to Swiss government bonds by Christensen and Krogstrup (2018). The figure, which depicts the term premium estimates since 2006, illustrates that the two approaches yield about the same level and, moreover, behave generally quite similar which is demonstrated with a correlation coefficient of about 0.54. Only, two periods with differences can be observed. First, the years 2010-2011. Second, the years 2013-2014. The differences between the two approaches might potentially occur due to two reasons. First, they reflect the difference in the approaches. Second, they may result because different products with different characteristics are used. On the one hand, Swiss government bonds are a cash instrument and prices could be influenced by flight-to-quality, liquidity and potentially also preferred habitat considerations. On the other hand, LIBOR futures are a standardized and CCP-cleared derivative which could potentially be affected by speculative flows and hedging needs. Overall, we conclude from the figure that the term premium in the CHF government bond market is closely linked to

Table 8 Interpolation of LIBOR futures

\begin{tabular}{lll}
\hline Libor futures (in \%) & $3 \mathrm{M}$ & $12 \mathrm{M}$ \\
\hline Spline interpolation & 1.917 & 2.171 \\
Polynomial interpolation (1 day) & 1.917 & 2.171 \\
Polynomial-spline (avg.) & 0.000 & 0.000 \\
| polynomial-spline | (avg.) & 0.002 & 0.002 \\
\hline
\end{tabular}

the term premium in LIBOR futures and that the two approaches provide quite similar estimations which is comparable to other currency areas (Cohen et al. 2018).

\subsection{Regression results by sub-periods}

We also tested how the regression results differ for the two monetary policy environments (see description in Section 3.2). To do so, we split the data in a period before and after 2000. The regression results for interest rate uncertainty are depicted in Table 9 . While the coefficients for realized interest rate uncertainty remain positive and statistically significant for both periods, the coefficients for expected interest rate uncertainty are only positive and statistically significant in the second period. This is potentially due to the rather few observations in the first period as the expected uncertainty variable is only available from June 1998 onwards. In line with the baseline analysis the coefficient for the VIX remain mostly statistically insignificant. Also the results with respect to economic variables (Table $7 \mathrm{~b}$ and c) remain generally unchanged but less significant. In particular changes in 3-month LIBOR rates are no longer significant for the second sub-period while the results for the $\mathrm{BCI}$ are still positive and statistically significant. Additionally, in the second period the coefficients for the strength of the CHF is not only negative but also statistically significant for the 12-month maturity, indicating that in periods of $\mathrm{CHF}$ appreciation the CHF forward term premium declines.

\section{Conclusion}

In this paper, we analyze excess returns of CHF LIBOR futures over the past 25 years. We find that excess returns are, on average, positive and statistically significant. Using interest rate surveys, we decompose excess returns into 


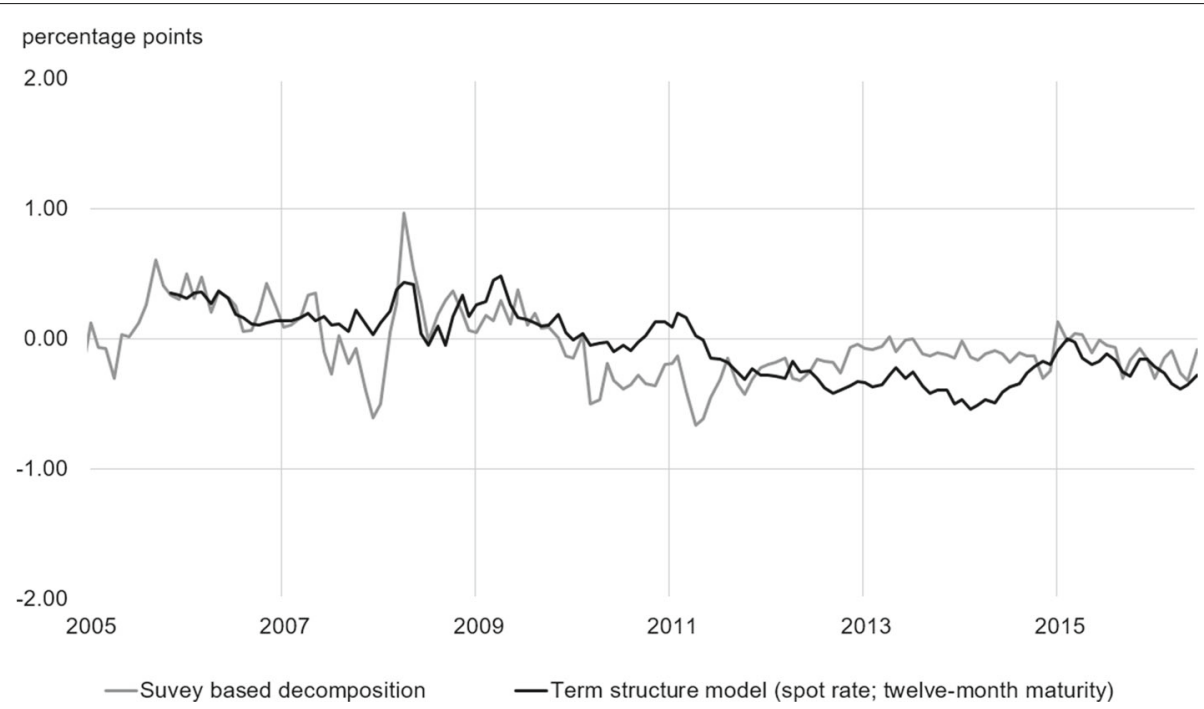

Fig. 8 Comparison of approaches. The figure compares the model-free estimation of the CHF term premium with the term premium obtained from an Arbitrage-Free Nelson-Siegel term structure model by Christensen and Krogstrup (2018)

a term premium and forecast errors. The large part of excess returns arises from forecast errors, while the term premium is, on average, zero but time varying.

Our regression results show that the size of the absolute term premium is positively correlated with interest rate uncertainty. Moreover, we show that variations in the term premium correlate to a considerable degree with changes in the Swiss business cycle index and short-term interest rates.

With the methodology and the data at hand, further research on the term premium in LIBOR futures can be done. For example, it might be worth investigating how the term premium reacts in response to unanticipated changes in monetary policy. Moreover, it could also be interesting to derive a daily estimation of the term premium, using financial market variables.

\section{Endnotes}

${ }^{1}$ The Chicago Mercantile Exchange describes Eurodollar futures with the following words: "Eurodollar futures prices reflect market expectations for interest rates on 3-month Eurodollar deposits for specific dates in the future.. See: www.cmegroup.com/trading/interest-rates/ introduction-to-eurodollar-futures-and-options.html

${ }^{2}$ We use for simplicity the notion term premium instead of forward term premium, which would be more precise as we analyze standardized interest rate forward contracts. Note that the terminology used in the existing literature is not homogeneous. For example, the term premium is sometimes called "risk premium" (Ferrero and Nobili
2009), "forward premium" (Gameiro 2006), and "original survey-based premium” (Ichiue and Yuyama 2009).

${ }^{3}$ LIBOR rates may be associated with some issues: First, several banks were fined for misconduct relating to LIBOR, in particular seeking to influence LIBOR contributions. These manipulations should, however, have a limited effect on our analysis, as the manipulations distorted LIBOR fixings only to a rather small degree (see, e.g., Abrantes-Metz et al. (2012)). Second, in the recent years the activity in the unsecured interbank market has declined substantially and e.g., CHF LIBOR rates are nowadays based on very few transactions (Moser (2017) and Guggenheim et al. (2011)). Third, the future of LIBOR is uncertain. End of July 2017 the Financial Conduct Authority announced that it would no longer be in a position to guarantee that banks submit contributions to LIBOR beyond the year 2021 (Bailey 2017).

${ }^{4}$ See also ICE product description: www.theice.com/ products/Futures-Options/Interest-Rates

${ }^{5}$ See SNB data portal: https://data.snb.ch/en.

${ }^{6}$ Recall that the price of a futures contract is defined as 100 minus the forward interest rate (see Section 3.1).

${ }^{7}$ Note that interest rate survey data are also available from other sources (see discussion in Section 7). Moreover, interest rate expectations could also be derived from option prices on LIBOR futures (Söderlind 2010). For the CHF market, this is currently not feasible, as the 
Table 9 Uncertainty and the size of the absolute term premium by sub-periods

\begin{tabular}{|c|c|c|c|c|c|c|}
\hline & (1) & $(2)$ & (3) & (4) & (5) & (6) \\
\hline & $\left|r_{3 M}\right|$ & $\left|r_{12 M}\right|$ & $\left|r_{3 M}\right|$ & $\left|r_{12 M}\right|$ & $\left|r_{3 M}\right|$ & $\left|r_{12 M}\right|$ \\
\hline \multicolumn{7}{|c|}{ (a) From March 1991 through December 1999} \\
\hline \multirow[t]{2}{*}{ Constant } & -0.13 & 0.09 & 0.33 & $0.63^{* * *}$ & $0.45^{* * *}$ & $0.66^{* * *}$ \\
\hline & $(0.11)$ & $(0.15)$ & $(0.2)$ & $(0.18)$ & $(0.12)$ & $(0.08)$ \\
\hline \multirow[t]{2}{*}{ VIX } & & & & & -0.01 & $-0.01^{* * *}$ \\
\hline & & & & & $(0.01)$ & $(0.00)$ \\
\hline \multirow[t]{2}{*}{ dispersion $_{12 M}$} & & & & -0.74 & & \\
\hline & & & & $(0.66)$ & & \\
\hline \multirow[t]{2}{*}{ dispersion $_{3 M}$} & & & -0.02 & & & \\
\hline & & & $(0.99)$ & & & \\
\hline \multirow[t]{2}{*}{$\operatorname{garch}_{12 M}$} & & $0.16^{* * *}$ & & & & \\
\hline & & $(0.06)$ & & & & \\
\hline \multirow[t]{2}{*}{$\operatorname{garch}_{3 M}$} & $0.27^{* * *}$ & & & & & \\
\hline & $(0.08)$ & & & & & \\
\hline Adjusted R ${ }^{2}$ & 0.24 & 0.12 & -0.06 & -0.03 & 0.02 & 0.03 \\
\hline Observations & 106 & 106 & 19 & 19 & 106 & 106 \\
\hline \multicolumn{7}{|c|}{ (b) From January 2000 through August 2016} \\
\hline \multirow[t]{2}{*}{ Constant } & 0.02 & 0.03 & $0.06^{* * *}$ & $0.11^{* * *}$ & $0.08^{* * *}$ & $0.19^{* * *}$ \\
\hline & $(0.03)$ & $(0.04)$ & $(0.02)$ & $(0.03)$ & $(0.02)$ & $(0.05)$ \\
\hline \multirow[t]{2}{*}{ VIX } & & & & & $0.00^{*}$ & 0.00 \\
\hline & & & & & $(0.00)$ & $(0.00)$ \\
\hline \multirow[t]{2}{*}{ dispersion $_{12 M}$} & & & & $0.43^{* * *}$ & & \\
\hline & & & & $(0.11)$ & & \\
\hline \multirow[t]{2}{*}{ dispersion $_{3 M}$} & & & $0.37^{* *}$ & & & \\
\hline & & & $(0.16)$ & & & \\
\hline \multirow[t]{2}{*}{ garch $_{12 M}$} & & $0.18^{* * *}$ & & & & \\
\hline & & $(0.04)$ & & & & \\
\hline \multirow[t]{2}{*}{$\operatorname{garch}_{3 M}$} & $0.11^{* * *}$ & & & & & \\
\hline & $(0.04)$ & & & & & \\
\hline Adjusted $R^{2}$ & 0.19 & 0.14 & 0.07 & 0.09 & 0.01 & 0.01 \\
\hline Observations & 200 & 200 & 200 & 200 & 200 & 200 \\
\hline
\end{tabular}

The table shows the regression results for uncertainty measures and the size of the absolute term premium for the two sub-periods. The uncertainty measure for futures is based on the GARCH model by Ding et al. (1993). The standard deviation of survey estimates is the standard deviation of all survey estimates for a specific survey date. The dataset contains monthly observations. Note that the standard deviation of survey estimates is not available for the entire sample period but only from June 1998 onwards, which reduces the number of observations in our regression analysis. Heteroscedasticity- and autocorrelation-consistent standard errors (in parentheses) are applied, using the Newey and West (1987) correction. The number of lags used equals the length of the contract (number of months).*****, and * denote statistical significance (two-tailed) at the $1 \%, 5 \%$, and $10 \%$ significance levels, respectively

trading activity in the interest rate option market is very low (see BIS Triennial Central Bank Survey 2016).

${ }^{8}$ The number of lags used equals the length of the contract (number of months). Note that our results remain statistically significant when using more conservative specifications of the number of lags.

${ }^{9}$ Interest rate uncertainty is typically measured using (i) disagreement among forecasters in interest rate surveys, (ii) volatility of forward interest rates and (iii) implied volatility derived from interest rate options. For the purpose of this paper, we do not use implied volatilities by option prices as they are rarely traded in CHF (see BIS Triennial Central Bank Survey 2016).

${ }^{10}$ Note that $\alpha, \beta, \gamma, \delta$ and $\omega$ represent model parameters, which are estimated by the quasi-maximum likelihood estimator. We use a Student's t-distribution for 
all contracts and estimate the degrees of freedom along with the other parameters. Moreover, we reject the null hypothesis of no conditional heteroscedasticity via the Ljung-Box statistic on the squared series.

${ }^{11}$ Note that we have also conducted a regression analysis using the squared value of the respective uncertainty measure as an additional independent variable to test for a non-linear relationship. However, using such a specification yields to similar results as in our baseline approach and the squared terms are not statistically significant.

${ }^{12}$ To measure the Swiss business cycle, the growth rate of the gross domestic product (GDP) would also be a suitable variable. However, this variable is only available on a quarterly frequency and reacts more slowly to economic changes. Hence, we focus on the BCI. Note that if the variable GDP instead of BCI is used in the regression analysis the coefficients are positive but no longer statistically significant.

${ }^{13}$ This is different than the prevalent term structure literature for which the existence of an effective lower bound increases estimation challenges because it introduces non-linearities into the term structure model. As a result, shadow-rate models emerged which sometimes incorporate survey data (see discussion in Section 2).

${ }^{14}$ Other interest rate surveys in $\mathrm{CHF}$ are, for example, the CS-CFA survey (formerly the CS-ZEW survey). However, these surveys are characterized by notable methodological differences, which makes a comparison with the Consensus survey difficult.

\section{Acknowledgements}

We thank Roman Baumann, Benjamin Brunner, Christian Grisse, Petra Gerlach, Christian Heppenstrick, Marco Huwiler, Daniel Kaufmann, Sébastien Kraenzlin, Cyril Monnet, Benjamin Müller, Thomas Nitschka, Steven Ongena, Silvio Schumacher, Eric Swanson, Cédric Tille (the editor), Kenneth West, Matthias Zwicker and three anonymous referees as well as the participants of the Finance Seminar at the University of Neuchatel 2018, the Annual Congress of the Swiss Society of Economics and Statistics 2017, the Brown Bag Seminar at the Swiss National Bank, and the Swiss National Bank Research Conference 2016 for helpful comments. The views expressed in this paper are those of the authors and do not necessarily reflect those of the SNB.

\section{Funding}

This research was not funded by external sources.

\section{Availability of data and materials}

The data that support the findings of this study are available from Bloomberg L.P. and Consensus Economics but restrictions apply to the availability of these data, which were used under license for the current study, and so are not publicly available. Data are however available from the authors upon reasonable request and with permission of Bloomberg L.P. and Consensus Economics.

\section{Authors' contributions}

All authors read and approved the final manuscript. All authors contributed equally to the article.
Competing interests

The authors declare they have no competing interests.

\section{Publisher's Note}

Springer Nature remains neutral with regard to jurisdictional claims in published maps and institutional affiliations.

Received: 13 July 2018 Accepted: 14 May 2019

Published online: 25 July 2019

\section{References}

Abrantes-Metz, R., Kraten, M., Metz, A., Seow, G. (2012). Libor manipulation? Journal of Banking \& Finance, 36(1), 136-150.

Bailey, A. (2017). The future of Libor, Speech by Andrew Bailey, Chief Executive of the FCA, at Bloomberg London, 27 July 2017. https://www.fca.org.uk/ news/speeches/the-future-of-libor.

Bernanke, B., \& Kuttner, K. (2005). What explains the stock market's reaction to federal reserve policy?. The Journal of Finance, 60(3), 1221-1257.

Brodsky, B., Del Negro, M., Fiorica, J., LeSueur, E., Morse, A., Rodrigues, A. (2016a). How do survey-and market-based expectations of the policy rate differ? Federal Reserve Bank of New York Liberty Street Economics (blog), April 7, 2016, https://libertystreeteconomics.newyorkfed.org/2016/04/how-dosurvey-and-market-based-expectations-of-the-policy-rate-differ.html.

Brodsky, B., Del Negro, M., Fiorica, J., LeSueur, E., Morse, A., Rodrigues, A. (2016b). Reconciling survey- and market-based expectations for the policy rate. Federal Reserve Bank of New York Liberty Street Economics (blog), April 8, 2016, https://ibertystreeteconomics.newyorkfed.org/2016/04/reconcilingsurvey-and-market-based-expectations-for-the-policy-rate.html.

de Bruin, W.B., Van der Klaauw, W., Topa, G., Downs, J.S., Fischhoff, B., Armantier, O. (2012). The effect of question wording on consumers' reported inflation expectations. Journal of Economic Psychology, 33(4), 749-757.

Christensen, J.H.E., Diebold, F.X., Rudebusch, G.D. (2011). The affine arbitrage-free class of nelson-siegel term structure models. Journal of Econometrics, 164(1), 4-20.

Christensen, J.H., \& Krogstrup, S. (2018). Transmission of quantitative easing: The role of central bank reserves. The Economic Journal, 129(617), 249-272.

Cohen, B., Hördahl, P., Xia, D. (2018). Term premia: models and some stylised facts. BIS Quarterly Review, Bank for International Settlements, September 2018 (pp. 79-91).

Crump, R., Eusepi, S., Moench, E. (2016). The term structure of expectations and bond yields. Staff Report, Federal Reserve Bank of New York No. 775.

Crump, R., Moench, E., O'Boyle, W., Raskin, M., Rosa, C., Stowe, L. (2014a). Interest rate derivatives and monetary policy expectations. Federal Reserve Bank of New York Liberty Street Economics (blog), December 5, 2014, https://libertystreeteconomics.newyorkfed.org/2014/12/interest-ratederivatives-and-monetary-policy-expectations.html.

Crump, R., Moench, E., O'Boyle, W., Raskin, M., Rosa, C., Stowe, L. (2014b). Survey measures of expectations for the policy rate. Federal Reserve Bank of New York Liberty Street Economics (blog), December 5, 2014, https:// libertystreeteconomics.newyorkfed.org/2014/12/survey-measures-ofexpectations-for-the-policy-rate.html.

Ding, Z., Granger, C.W.J., Engle, R.F. (1993). A long memory property of stock market returns and a new model. Journal of Empirical Finance, 1(1), 83-106.

European Central Bank (2005). Monetary and financial developments. ECB Monthly Bulletin, September, 24-27. https://www.ecb.europa.eu/pub/pdf/ mobu/mb200509en.pdf.

Fama, E., \& Bliss, R. (1987). The information in long-maturity forward rates. The American Economic Review, 77(4), 680-692.

Ferrero, G., \& Nobili, A. (2009). Futures contract rates as monetary policy forecasts. International Journal of Central Banking, 43(23), 3213-3230.

Friedman, B. (1979). Interest rate expectations versus forward rates: evidence from an expectations survey. The Journal of Finance, 34(4), 965-973.

Froot, K. (1989). New hope for the expectations hypothesis of the term structure of interest rates. The Journal of Finance, 44(2), 283-305.

Galli, A. (2018). Which indicators matter? analyzing the Swiss business cycle using a large-scale mixed-frequency dynamic factor model. Journal of Business Cycle Research, 14(2), 179-218.

Gameiro, I. (2006). Estimating forward premiums of short-term interest rates based on survey results. Banco de Portugal Economic Bulletin, Q3, 109-119. 
Geiger, F., \& Schupp, F. (2018). With a little help from my friends: Survey-based derivation of euro area short rate expectations at the effective lower bound. Deutsche Bundesbank: Discussion Paper No. 27.

Gerlach-Kristen, P. (2007). Three aspects of the Swiss term structure: an empirical survey. Financial Markets and Portfolio Management, 21(2), $221-240$.

Gibson, R., Lhabitant, F.-S., Talay, D., et al. (2010). Modeling the term structure of interest rates: A review of the literature. Foundations and Trends ${ }^{\circledR}$ in Finance, 5(1-2), 1-156.

Grishchenko, O.V., \& Huang, J-Z. (2013). The inflation risk premium: evidence from the TIPS market. The Journal of Fixed Income, 22(4), 5-30.

Grisse, C., \& Schumacher, S. (2018). Term structure dynamics at low and negative interest rates-evidence from Switzerland. Swiss Journal of Economics and Statistics, 154(1), 1-20.

Guggenheim, B., Kraenzlin, S., Schumacher, S. (2011). Exploring an Uncharted Market: Evidence on the Unsecured Swiss Franc Money Market. Aussenwirtschaft, 66(1), 58-89.

Hsu, C., Kugler, P., et al. (1996). Demand for Reserves and the Central Bank's Management of Interest Rates. Swiss Journal of Economics and Statistics, $132,153-176$.

Ichiue, H., \& Yuyama, T. (2009). Using survey data to correct the bias in policy expectations extracted from fed funds futures. Journal of Money, Credit and Banking, 41(8), 1631-1647.

Jordan, T. (2012). Introductory remarks by Thomas Jordan. SNB Monetary policy assessment, 14 June 2012. https://www.snb.ch/en/mmr/speeches/ id/ref_20120614_tjn/source/ref_20120614_tjn.en.pdf.

Kim, D.H., \& Orphanides, A. (2012). Term structure estimation with survey data on interest rate forecasts. Journal of Financial and Quantitative Analysis, $47(1), 241-272$

Kim, D., \& Orphanides, A. (2007). The bond market term premium: what is it, and how can we measure it? BIS Quarterly Review, Bank for International Settlements, June, 27-40.

Kim, D., \& Tanaka, H. (2016). Front-end term premiums in federal funds futures rates and implied probabilities of future rate hikes. FEDS Notes, Board of Governors of the Federal Reserve System, November 18, 2016, https://doi. org/10.17016/2380-7172.1884.

Kugler, P. (1988). An empirical note on the term structure and interest rate stabilization policies. The Quarterly Journal of Economics, 103(4), 789-792.

Kugler, P. (1996). The term structure of interest rates and regime shifts: some empirical results. Economics Letters, 50(1), 121-126.

Kugler, P. (1997). Central bank policy reaction and the expectations hypothesis of the term structure. International Journal of Finance Economics, 2(3), 217-224.

Moser, D. (2017). The international reform process so far and the importance of interest rate benchmarks from a central bank perspective. Speech by Dewet Moser, Alternate Member of the Governing Board of the Swiss National Bank, 22 September 2017. https://www.snb.ch/en/mmr/ speeches/id/ref_20170922_mo/source/ref_20170922_mo.en.pdf.

Müller, R. (2017). The new SNB exchange rate index. SNB Economic Studies. No. 11.

Newey, W., \& West, K. (1987). A simple, positive semi-definite, heteroskedasticity and autocorrelation consistent covariance matrix. Econometrica, 55(3), 703-708.

Peacock, C. (2004). Deriving a market-based measure of interest rate expectations. Bank of England Quarterly Bulletin, Q2, 142-152.

Phillot, M., \& Rosenblatt-Wisch, R. (2018). Inflation expectations: The effect of question ordering on forecast inconsistencies. SNB Working Paper. No. 2018-11.

Piazzesi, M., \& Swanson, E. (2008). Futures prices as risk-adjusted forecasts of monetary policy. Journal of Monetary Economics, 55(4), 677-691.

Priebsch, M.A. (2017). A Shadow Rate Model of Intermediate-Term Policy Rate Expectations. FEDS Notes, Board of Governors of the Federal Reserve System, October 4, 2017, https://doi.org/10.17016/2380-7172.2056.

Söderlind, P. (2010). Reaction of swiss term premia to monetary policy surprises. Swiss Journal of Economics and Statistics, 146, 385-404.

Swiss National Bank (1999). Anpassung des geldpolitischen Konzeptes. SNB Quarterly Bulletin, Q4, 1-23.

Veyrassat, A. (2004). The Swiss franc money market: instruments and market participants. SNB Quarterly Bulletin Q3, 42-55.
Wright, J.H. (2011). Term premia and inflation uncertainty: Empirical evidence from an international panel dataset. American Economic Review, 101(4), 1514-34.

Zarnowitz, V., \& Lambros, L. (1987). Consensus and uncertainty in economic prediction. Journal of Political Economy, 95(3), 591-621.

\section{Submit your manuscript to a SpringerOpen ${ }^{\circ}$ journal and benefit from:}

- Convenient online submission

- Rigorous peer review

- Open access: articles freely available online

- High visibility within the field

- Retaining the copyright to your article

Submit your next manuscript at $>$ springeropen.com 